\title{
Particle Size's Effect of Application Forage Processing Technology on Consumption Efficiency, Palatability and Digestibility of Local Goat
}

\author{
Retno Iswarin Pujaningsih, Furiska Fani and Andre Wira Pambudi \\ Faculty of Animal Agriculture, Diponegoro University, Semarang, Indonesia \\ Corresponding author email: retno.marwoto@gmail.com
}

\begin{abstract}
Livestock's digestible feed ability is affected by the physical and chemical quality of the feed given. Study on feed processing application on a local goat feed particle size needs to be done for efficiency of feeding patterns. This study aimed to evaluate the best forage particle size on efficiency consumption, palatability and digestibility of the local goat. The experimental method was done with randomized completely block design with $3 \times 2 \times 3$ factorial. Goats are grouped by weight, the first factor is the form of feed (fresh, dried) with particle feed size of 3,5, and $>7 \mathrm{~cm}$ as the second factor. The results showed that particle size of $>7 \mathrm{~cm}$ gives the optimal feed consumption and palatability. Dry and organic materials digestibility provided the best on the particle size of $3 \mathrm{~cm}$. Forms of dry feed has a positive correlation to consumption, palatability and digestibility of feed. Study recommended dried forage given to the local goats with a particle size of $3 \mathrm{~cm}$ is able to provide efficiency in consumption and palatability of the feed with the most excellent digestibility.
\end{abstract}

Key words: particle size, local goat, palatability, digestibility, feed consumption

Abstrak. Kemampuan ternak untuk mencerna pakan dipengaruhi oleh kualitas fisik dan kimia dari pakan yang diberikan. Kajian aplikasi pengolahan pakan pada ukuran partikel pakan kambing lokal perlu dilakukan untuk efisiensi pola pemberian pakan. Penelitian ini ditujukan untuk mengevaluasi ukuran partikel pakan hijauan kambing lokal yang memiliki efisiensi konsumsi, palatabilitas dan kecernaan terbaik. Metode eksperimental dilakukan dengan rancangan acak kelompok pola faktorial $3 \times 2 \times 3$. Kambing dikelompokkan berdasarkan berat badan, faktor pertama adalah bentuk pakan (segar, kering) dengan ukuran partikel pakan $3-5->7 \mathrm{~cm}$ sebagai faktor kedua. Hasil penelitian menunjukkan bahwa konsumsi dan palatabilitas optimal pada ukuran partikel $>7$ $\mathrm{cm}$. Kecernaan Bahan Kering dan Organik terbaik pada ukuran partikel $3 \mathrm{~cm}$. Bentuk pakan kering memiliki korelasi positif terhadap konsumsi, palatabilitas dan kecernaan pakan. Simpulan penelitian merekomendasikan hijauan pakan kering yang diberikan pada kambing lokal dengan ukuran partikel $3 \mathrm{~cm}$ mampu memberikan efisiensi konsumsi dan palatabilitas pakan dengan kecernaan yang paling baik.

Kata kunci: ukuran pakan, kambing lokal, palatabilitas, kecernaan, konsumsi pakan

\section{Introduction}

Goat farming system in Indonesia is still largely traditional, especially on feeding patterns feed. Using forage as a single feed for local goat will cause on low productivity. This is due to the lack of forage nutrient content that does not meet the basic needs of goats (Dony et al., 2014). Feed quality will be determined also by the value of digestibility. Values obtained from the difference between the digestibility of nutrients consumed with nutrients excreted and deemed to have been absorbed by the digestive tract. So the value reflects the nutrient digestibility of feed that can be used by livestock (Sandi et al., 2015).

Another aspect to be considered is the palatability of feed for goat as herbivores selective feed. One way of goat's feed selecting is over feed particle size (Basri, 2014). Palatability is the response given by the feed given to the goat. The ability of livestock to digest feed deeply influenced by the performance and the physical condition of the feed material processed. Livestock will be easier to accept and attracted to the food particles 
that are easier to digest. Improved digestibility will lead to increased consumption.

Feed processing technology that is easy, inexpensive and able to improve feed efficiency is urgently needed to address the scarcity of food availability in the dry season. Chopping and drying the feed are a practical method that is easily applied by farmers. Chopping is a form of feed processing that aims to change the particle size of materials that affect the palatability of livestock. Described by Welch and Hooper (1988), the size of feed particles which can be regurgitated is on a maximum of 7 $\mathrm{cm}$, whereas rumination activity will be stimulated properly by the feed particles must be at least of $10 \mathrm{~mm}$. According to the Church (1988) feed particles with sizes less than $1 \mathrm{~mm}$ will easily pass through the rumen to the omasum. Referring to Pujaningsih et al. (2010) particle size reduction in raw material for feed milling process wafers can improve digestibility of feed ingredients. Results study by Ruckebush (1988) showed that the form of feed affects the contraction in the rumen. The small particle size of forage is reported by Bhatti et al. (2008) has a fast feed flow rate.

This study aims to assess the application of forage feed processing technology on consumption efficiency, palatability and digestibility of local goats. It is hoped information about the shape and size of the feed particles feed materials that optimize feed efficiency can be applied easily by farmers.

\section{Materials and Method}

\section{Research material}

The main material is the feed and 12 female goats in 4 blocks of weight. Feed material consisting of elephant grass which was chopped on 3 (T1), 5 (T2) and $>7$ (T3) cm. It was given dried and fresh.

\section{Research method}

The experimental method was done with randomized completely block design with $4 \times 2 \times 3$ factorial. Goats are grouped by weight, the first factor is the form of feed (fresh, dried) with particle feed size of 3,5 , and $>7 \mathrm{~cm}$ as the second factor. Fresh feed given soon after being treated. Dry feed given after dried in the sun until the moisture content ranges from 16$18 \%$. Consumptions, palatability and digestibility of feed were observed as parameters.

\section{Technique for data collection}

Feed was weighed before given twice a day at 08:00 and 16:00 hours. The remaining feed and total goat's dung collections were weighed every morning of the next day. Data collection for seven days after two-week of adaptation period (Soita et al., 2000). Measurement of feed digestibility performed in vivo by using lignin indicator. The measurement refers to the method of nutrient digestibility by Sales et al. (2004).

\section{Processing and data analysis}

Data were processed using SPSS 16 for Windows to determine the influence of each treatment. Followed by Duncan's test multiple areas.

\section{Results and Discussion}

\section{Feed consumption and palatability}

Based on statistical test, the differences weight of goats in each group did not affect feed intake both in treatment of feed size and feedform (fresh and dried). There are significant differences $(P<0.05)$ on feed intake in feed particle size of $3 \mathrm{~cm}$ to $>7 \mathrm{~cm}$ in two forms of feed. In Table 1, the result of Duncan's test multiple areas showed that palatability of the treatment was not significantly different upon T3 and T2 but significantly different $(P<0.05)$ with T1. The palatability value treatment of $\mathrm{T} 1$ is significantly different $(P<0.05)$ with $T 2$.

The sum of palatability from the three treatments obtained the highest value in the treatment of $<7 \mathrm{~cm}$ size forage T3 $(3.466 \mathrm{~kg})$ as compared to treatment palatability T1 (3.035 $\mathrm{kg})$ and T2 (3.451 kg). 
Table 1. Feed consumption of Local Goat in Some Particle Feed Size and Form

\begin{tabular}{|c|c|c|c|c|c|c|}
\hline \multirow{2}{*}{$\begin{array}{l}\text { Feed form } \\
\text { (i) }\end{array}$} & \multirow{2}{*}{$\begin{array}{l}\text { Particle Feed Size } \\
\text { (cm) } \\
\text { (j) }\end{array}$} & \multicolumn{4}{|c|}{ Block of Weight (k) } & \multirow{2}{*}{ Means } \\
\hline & & 1 & 2 & 3 & 4 & \\
\hline \multirow{3}{*}{ Fresh } & $\mathrm{T} 1$ & 2.22 & 2.23 & 2.81 & 2.33 & $2.40^{\mathrm{A}}$ \\
\hline & $\mathrm{T} 2$ & 1.71 & 1.80 & 1.63 & 2.28 & $1.86^{\mathrm{B}}$ \\
\hline & T3 & 2.07 & 2.11 & 2.59 & 3.00 & $2.44^{\mathrm{A}}$ \\
\hline \multirow{3}{*}{ Dry } & $\mathrm{T} 1$ & 2.60 & 2.91 & 2.86 & 3.77 & $3.04^{b}$ \\
\hline & $\mathrm{T} 2$ & 3.08 & 3.07 & 3.68 & 3.97 & $3.45^{\mathrm{a}}$ \\
\hline & T3 & 2.86 & 3.33 & 3.60 & 4.07 & $3,47^{a}$ \\
\hline
\end{tabular}

Based on these results indicate that goat prefer to receive forage with a larger size at T3 treatment than the treatment of $\mathrm{T} 1$ and $\mathrm{T} 2$. This is because the $\mathrm{T} 3$ feed treatment has a particle size similar to basal feed so that the goats have become accustomed to feeding forages with full size. Overall lead feed consumption at higher of T3. This is supported by the means of their mobile upper lips and very prehensile tongue, goats are able to graze on very short grass and to browse on foliage not normally eaten by other domestic livestock (Ginane et al., 2015).

Differences in treatment consumption $\mathrm{T} 3$ with $\mathrm{T} 1$ and $\mathrm{T} 2$ is related to the effect of palatability according Tobing opinion (2010) in Murni et al. (2012) which states that the palatability be one of the factors that affect the size of feed consumption. Feeding behavior of goat as a browser causes this livestock has high selective properties that make goats have the ability to select preferred feed. In the opinion of Church and Pond (1988) cited by Widiarti (2008) states that the palatability is defined as the response given by the feed given to the goat. Forbes and Mayes (2002) cited by Murni et al. (2008) adds that the animal has the palatability to choose feed through sight, smell, and taste.

Based on the research, goat prefer to consume dry feed more than the wet feed. According to Gusha et al. (2014) they dislike wet, stale or trampled fodder. For this reason, it is advisable to feed them in hay-racks or hang the feed-in bundles from a peg in the wall or from a branch of a tree. Double-sided portable hay-racks are the most suitable and convenient for feeding stall. Dry feed intake is highest in T3 treatment with consumption of $2.44 \mathrm{~kg} /$ day, followed by T1 (2.40 kg / day) and T2 (1.86 kg / day). This is due to the goats which are familiar on the feed with a particle size of more than 7 $\mathrm{cm}$. Ginane et al. (2015) states that consumption tends to be higher for livestock that used to feed against the feed that was given. Furthermore, Murni et al. (2012) pointed out that consumption is affected by age, level of production, and form feed.

T1 feed intake was not significantly different ( $P>0.05)$ with feed intake T3. This is due to its small size $($ size $<3 \mathrm{~cm})$. Feed with a small size will speed up the release rate of feed from the gastrointestinal tract, so that consumption will also increase. This is in accordance with the opinion of Ginting (2012) which states that the rate of digestion of feed will increase if the feed size is smaller, so that consumption levels will rise. In addition, the ration dry conditions cause many cattle drink. Drinking water will accelerate gastric emptying. Murni et al. (2012) suggest drinking lots of water will increase the rate of digestion and hydrolysis feed.

$\mathrm{T} 2$ as diet treatment had consumption levels that were significantly different $(P<0.05)$ with $\mathrm{T} 1$ and T3. T2 has a consumption rate of at least due to forage chopped size of medium (size 3-5 $\mathrm{cm}$ ) that made it voluminous fullfill the rumen. Ginting (2012) states the feed chopping 
processing would increase the density and expand the feed. Feed with a higher density will more quickly meet the rumen. According Church (1988) consumption of animal feed is physically limited by the ability to accommodate feed rumen (distention of the rumen).

\section{Dry and organic matter digestibility}

The results showed that the treatment of the feed size have significant effect $(P<0.05)$ digestibility of feedstuffs. Data digestibility of dry matter and organic matter of the feedstuffs can be seen in Table 2 and 3 . Overall, the digestibility of the feedstuffs research both fresh and dried forms were higher compare to standard goat for maintenance needs (60-70\%). It is caused by a crude fiber content of the feedstuffs which is low at $12.83 \%$ (results of laboratory analysis of Nutrition Feed Science Diponegoro University, 2016). Digestibility will increase if the feedstuffs containing low crude fiber. This result was in line with Pujaningsih et al. (2009) which concluded by the research's result that feed digestibility depend on undigestible fat content.

Another factor that causes high digestibility of feed material is the high protein of feed ingredients at $14.01 \%$ (results of laboratory analysis of Nutrition Feed Science Diponegoro University, 2016). Diet with enough protein will stimulate the growth and activity of rumen microbes. According to Koddang (2008), highprotein feed will supply the needs of the microbes to grow and the activity that resulted in increasing fermentative digestion resulting in dry matter ration higher. The highest feedstuffs digestibility obtained at T1 treatment followed by $\mathrm{T} 2$ and $\mathrm{T} 3$ at the Lowest value. $\mathrm{T} 1$ dry matter digestibility was not significantly different ( $P>$ 0.05 ) with a dry matter digestibility of $T 2$, but significantly different $(P<0.05)$ with T3.

Based on these results indicate that size affects the value of feed digestibility. The feed material particles with size $>7 \mathrm{~cm}$ will reduce digestibility. Digestibility results will affect the number of livestock consumption, so that when the digestibility is low, it will lead to increased consumption. This is because the fast rate of digesta in the digestive tract has speed the feed into a fast exit. This has led to increased feed consumption at T3 because it has result of low digestibility. While on treatment T1 feed digestibility generated higher, but consumption is low due to a slower rate of digesta resulting feed can not be quickly out of the digestive tract. This is in accordance with the opinion of Church and Pond (1988) which states that affect the digestibility of feed intake. Low digestibility can increase feed intake due to the rate of digesta in the digestive tract more quickly and ration would be quickly out of the digestive tract. So as to minimize the possibility of microbes and enzymes to digest food.

Particle size reduction can improve the digestibility of feed. This is in accordance with

Table 2. Dry Matter Digestibility Feed of Local Goat in Some Particle Feed Size and Form

\begin{tabular}{|c|c|c|c|c|c|c|}
\hline \multirow{2}{*}{$\begin{array}{l}\text { Feed form } \\
\text { (i) }\end{array}$} & \multirow{2}{*}{$\begin{array}{l}\text { Particle Feed } \\
\text { Size (cm) } \\
\text { (j) }\end{array}$} & \multicolumn{4}{|c|}{ Block of Weight (k) } & \multirow[t]{2}{*}{ Means } \\
\hline & & 1 & 2 & 3 & 4 & \\
\hline \multirow{3}{*}{ Fresh } & T1 & 81.78 & 78.73 & 78.28 & 76.10 & $78.72^{\mathrm{A}}$ \\
\hline & $\mathrm{T} 2$ & 74.46 & 73.06 & 75.02 & 77.72 & $75.07^{\mathrm{A}}$ \\
\hline & T3 & 69.96 & 72.99 & 73.51 & 72.19 & $72.16^{\mathrm{B}}$ \\
\hline \multirow{3}{*}{ Dry } & $\mathrm{T} 1$ & 83.71 & 86.41 & 91.16 & 86.11 & $86.85^{a}$ \\
\hline & $\mathrm{T} 2$ & 78.06 & 78.37 & 81.73 & 85.91 & $81.02^{\mathrm{a}}$ \\
\hline & T3 & 55.33 & 74.68 & 81.06 & 73.82 & $71.22^{b}$ \\
\hline
\end{tabular}


Table 3. Organic Matter Digestibility Feed of Local Goat in Some Particle Feed Size and Form

\begin{tabular}{|c|c|c|c|c|c|c|}
\hline \multirow{2}{*}{$\begin{array}{l}\text { Feed form } \\
\text { (i) }\end{array}$} & \multirow{2}{*}{$\begin{array}{c}\text { Particle Feed } \\
\text { Size }(\mathrm{cm}) \\
\text { (j) }\end{array}$} & \multicolumn{4}{|c|}{ Block of Weight (k) } & \multirow{2}{*}{ Means } \\
\hline & & 1 & 2 & 3 & 4 & \\
\hline \multirow{3}{*}{ Fresh } & $\mathrm{T} 1$ & 84.87 & 81.72 & 81.24 & 79.84 & $81.92^{\mathrm{A}}$ \\
\hline & $\mathrm{T} 2$ & 77.65 & 76.57 & 79.18 & 80.98 & $78.60^{\mathrm{AB}}$ \\
\hline & T3 & 74.28 & 77.13 & 77.40 & 75.98 & $76.20^{\mathrm{B}}$ \\
\hline \multirow{3}{*}{ Dry } & $\mathrm{T} 1$ & 84.36 & 86.62 & 91.74 & 86.33 & $87.26^{\mathrm{a}}$ \\
\hline & $\mathrm{T} 2$ & 84.90 & 84.53 & 87.36 & 90.89 & $86.92^{\mathrm{a}}$ \\
\hline & T3 & 63.90 & 79.93 & 84.92 & 80.01 & $77.19^{b}$ \\
\hline
\end{tabular}

the opinion of Pujaningsih et al. (2010) and Gusha et al. (2014) which states that the processing of the feed into a smaller form factor will increase the digestibility and palatability of livestock. This was confirmed by Ginane et al. (2015) which states forage digestibility is influenced by various factors, including temperature, speed of feed rate passage through the digestive tract, the physical form of feed, feed composition and comparison with the influence of other substances. In addition, feed in small size will facilitate fermentative digestion of feed. According Ginting (2012) feed treated by chopping or grounding will remodel the cell wall, including lignin in it and extending the feed so that the surface particle of rumen microorganisms can directly digest cellulose.

Organic matter digestibility results are not much different with feed digestibility of dry material. This is due to the organic matter digestibility have a well-built connection with dry matter digestibility of feed. This is in accordance with the opinion of Widodo et al. (2012) which states that the dry matter closely related to the organic matter digestibility because most of the dry matter consists of organic materials, the differences were located only on the ash. In addition, the nutrient content of the feedstuffs upon treatment $\mathrm{T} 1, \mathrm{~T} 2$ and T3 are the same. Sandi et al. (2013) stated that the same nutrients feed ingredients allows organic matter digestibility of dry matter digestibility in tune with. Organic matter digestibility indicates that nutrients are able to highly digest by the goats. According to Widodo et al. (2012) the amount of organic matter digestibility of nutrients is contained in the feed material includes protein, carbohydrates, fats and vitamins that can be digested by the livestock.

Based on statistical analysis there is no interaction between the feed size to feed form. The data in Table 3 and 4 show that the digestibility of the feed is higher in value on dry feed. Refer to Pujaningsih et al. (2010) hay has a range of minimum and maximum values which are relatively smaller than the fresh feed. This condition indicates that the physical form of hay as dried feed has a flow rate of feed passage which is better than fresh feed so that the rumen is able to accommodate the feed with an amount equivalent to the nutritional needs of goats.

\section{Conclusions}

The study of feeding fresh and dried feed on some feed size concluded that dried forage given to the local goats with a particle size of 3 $\mathrm{cm}$ is able to provide efficiency in consumption and palatability of the feed with the most excellent digestibility.

\section{References}

Basri. 2014. Dry and Organic Matter Digestibility of Complete Rations with Different Protein Content on the Male Goats Marica. University of Hasanuddin Makasar (Essay)

Bhatti SA, JGP Bowman, JL Firkins, AV Grove and CW Hunt. 2008. Effect of intake level and alfalfa 
substitution for grass hay on ruminal kinetics of fiber digestion and particle passage in beef cattle. J. Anim Sci. 86:134-145.

Church DC. 1988. The ruminant animal, digestive physiology and nutrition. $3^{\text {rd }}$. Prentice Hall of New Jersey. New Jersey.

Church DC and WG Pond. 1988. Basic Animal Nutrition on Feeding. $3^{\text {rd }}$ Ed., John Wiley and Sons, New York. 13,45,117.

Dony R, F Farida and Erwanto. 2014. Effect of Balance Forage Concentrate Against the Dry and Organic Matter Digestibility, and Protein Organic Digestibility of PE Goat Male in Tropic. Journal of Integrated Ranch Science. UNILA. Vol 2, No 1

Ginting SP. 2012. Prospects on application of technology processing based on feed by product of plantation industry in small ruminants. Wartazoa Vol. 22(2).

Ginane C, M Bonnet, R Baumont and DK Revell. 2015. Feeding behaviour in ruminants: a consequence of interactions between a reward system and the regulation of metabolic homeostasis. Animal Production Science 55(3) 247-260. http://dx.doi.org/10.1071/AN14481

Gusha J, EH Tinyiko, K Simbarashe and IZ Plaxedis . 2014. Performance of goats fed on low quality veld hay supplemented with fresh spiny cactus (Opuntia megacantha) mixed with browse legumes hay in Zimbabwe. Tropical Animal Health and Production. 46(7):1257-1263

Koddang MYA. 2008. Effect of feeding concentrate level on the digestibility of dry matter and crude protein ration upon Bali cattle males fed by ad libitum King grass (Pennisetum purpurephoides). Journal of Agroland 15(4):343 - 348

Murni R, Akmal and Y Okrisandi. 2012. Utilization of fermented cocoa skin with fungus Phanerochaete chrysosporium as a substitute in goats forage diet. Journal of Agrinak March 2012. 2(1):6-10.

Pujaningsih RI, Cl Sutrisno and Y Supriondho. 2010. Study on Anoa's Feed Form Preference Towards
Ex Situ Conservation And Cultivation. Journal of Animal Production UNSOED. 12(3): 150-155.

Pujaningsih RI, Cl Sutrisno, Y Supriondho, A Malik, Djuwantoko, S Pudyatmoko, MA Amir and S Aryanto. 2009. Diet composition of Anoa (Buballus Sp.) using direct observation and dung analysis method in their habitat towards its beneficial as prospective farm animal. Journal of the Indonesian Tropical Animal Agriculture. 34(3):223-227.

Retnani Y, W Widiarti, I Amiroh, L Herawati and KB Satoto. 2009. The Ability of Store and Palatability of Wafer Complete Rations Buds and Sugarcane Dregs for Calf. Media Peternakan. 32(2): 81-154.

Ruckebush Y. 1988. Motility of the gastro-intestinal tract. In: The Ruminant Animal, Digestive Physiology and Nutrition. Edited by D.C. Church. Prentice Hall, New Jersey. pp.73-107

Sandi S, AIM Ali and AA Akbar. 2015. In Vitro Test on Wafer Complete Rations with Different Binding Agent. Journal of Animal Husbandry Sriwijaya. $4(2)$.

Sales J, L de Schutter and GPJ Janssens. 2004. The use of internal markers to determine metabolizable energy and digestibility of diets in the African grey parrot (Psittacus erithacus). Vlaams Diergeneeskundig Tijdschrift. 73:176-181.

Soita HW, DA Christensen and JJ McKinnon. 2000. Influence of particle size on the effectiveness of the fiber in barley silage. J. Dairy Sci. 83:22952300.

Welch JG and AP Hooper. 1988. Ingestion of feed and water. In: The Ruminant Animal, Digestive Physiology and Nutrition. Edited by D.C. Church. Prentice Hall, New Jersey. pp.108-116

Widodo, F Wahyono dan Sutrisno. 2012. Dry matter digestibility, organic production of VFA and NH3 complete feed with different levels of rice straw upon in vitro. Animal Agricultural Journal 1(1):215-230. 